Jurnal Onoma: Pendidikan, Bahasa dan Sastra

ISSN 2443-3667 (print)

PBSI FKIP Universitas Cokroaminoto Palopo

ISSN 2715-4564 (online)

Volume 6 Nomor 2

\title{
Kemampuan Menggunakan Kata Penghubung dalam Karangan Eksposisi Mahasiswa Teknik Informatika Kelas I.F Universitas Cokroaminoto Palopo
}

\author{
Darmawati \\ Program Studi Informatika \\ Fakultas Komputer \\ me_darma@yahoo.com
}

\begin{abstract}
Abstrak
Penelitian ini merupakan penelitian deskriptif dengan teknik pengumpulan data melalui tes dan teknik analisis data. Penelitian ini bertujuan memperoleh gambaran yang lengkap dan seksama tentang kemampuan menggunakan kata penghubung dalam karangan Eksposisi Mahasiswa Teknik Informatika Kelas I.F Universitas Cokroaminoto Palopo. Mahasiswa yang menjadi sampel sebanyak 40 Mahasiswa. Objek penelitian dalam penelitian ini adalah penggunaan kata penghubung pada karangan Eksposisi. Data dalam penelitian ini adalah penggunaan kata penghubung dalam karangan Eksposisi Mahasiswa. Sumber dalam penelitian ini adalah sumber data tertulis yang berbentuk karangan Mahasiswa. Teknik pengumpulan data dalam penelitian ini adalah teknik simak dan catat. Hasil penelitian ini dapat disimpulkan bahwa penggunaan kata penghubung dalam karangan Eksposisi Mahasiswa Teknik Informatika Kelas I.F Universitas Cokroaminoto Palopo cukup baik, hanya saja masih ada beberapa Mahasiswa yang dalam penggunaan kata penghubung hanya berfokus pada kata penghubung yang sering digunakan.
\end{abstract}

Kata Kunci: Kata penghubung, Mahasiswa, Informatika

\section{Pendahuluan}

Para ahli bahasa selalu menghimbau agar pemakaian bahasa senantiasa berusaha untuk menggunakan bahasa Indonesia yang baik dan benar. Ini menunjukkan bahwa, masih sering ditemukan kesalahan berbahasa dalam proses kehidupan bermasyarakat, yang menggunakan bahasa sebagai alat komunikasi. Kesalahan berbahasa ini tidak hanya terjadi pada orang-orang awam yang belum mengecap ilmu pengetahuan di sekolah atau perguruan tinggi tertentu, tetapi sering pula dilakukan oleh kaum intelektual dan mereka yang telah memegang jabatan penting dalam bidang pemerintahan. Menurut Kridalaksana (dalam Chaer, 2007:52) bahasa adalah sistem lambing bunyi yang arbiter yang digunakan oleh para anggota kelompok sosial untuk kerjasama, berkomunikasi, dan mengidentifikasi diri. Alat komunikasi manusia yang merupakan lambing bunyi ujaran yang digunakan untuk berkomunikasi oleh masyarakat pemakainnya. Secara sederhana bahasa adalah suatu system yang bersifat sistematis dan sekaligus sistemis (Chaer, 2007: 4-5).

Merujuk dari pendapat para ahli diatas, maka peneliti dapat menyimpulkan bahwa bahasa adalah alat untuk berkomunikasi dengan lingkungan sosial, sekolah, maupun lingkungan teman sepermainan. Melalui bahasa kita dapat menyatukan pendapat, perasaan, dan gagasan yang terkandung dalam pikiran kita terhadap orang lain. Salah satu usaha untuk meningkatkan mutu pengetahuan bahasa dan sastra Indonesia di sekolah adalah pendidikan di bidang kelas kata. Ruang lingkup kajian kelas kata cukup luas dan kompleks. Agar pembahasan di dalam laporan penelitian ini 
tidak mengambang, peneliti hanya mengkaji satu aspek kajian kelas kata, yaitu kata penghubung dalam karangan Mahasiswa. Penelitian tertarik pada aspek kajian ini, karena di kalangan Mahasiswa Teknik Informatika Kelas I.F Universitas Cokroaminoto Palopo masih banyak yang belum mampu menganalisis dan menggunakan kata penghubung dalam menulis sebuah karangan. Menurut Ambary (1983: 132) kata sambung atau kata penghubung ialah kata yang bertugas menghubungkan kalimat, bagian kalimat atau kata dengan sekaligus menentukan macam hubungannya. Menurut Kridalaksana (1997: 235) kata tugas yaitu yang menghubungkan dua klausa atau lebih atau konjungsi merupakan kata sambung.

\section{Metode Penelitian}

Metode penelitian adalah cara atau langkah-langkah yang akan dilakukan dalam penelitian untuk mendapatkan kebenaran yang representative dan mengarah pada tujuan yang harus memiliki prosedur secara tepat. Memiliki prosedur yang tepat merupakan bagian yang ikut menentukan dalam kebenaran hasil penelitian. Penelitian akan berjalan lancer jika kita menggunakan metode yang tepat dan sesuai. Berdasarkan hal di atas, bentuk penelitian yang akan digunakan dalam penelitian ini adalah Eksposisi kualitatif, yaitu penelitian yang dilakukan dengan cara mengumpulkan data berupa kata-kata, gambar, bukan angka dan disampaikan dalam bentuk verbal. Sepertihanlya pendapat Subroto (1992:7) penelitian yang dilakukan dengan cara peneliti mencatat data-data yang berwujud kata-kata, kalimat, wacana, gambar, foto, catatanharian, memorandum, dan video tape. Pada penelitian ini peneliti menitik beratkan pada deskriptif kualitatif yang bertujuan untuk menggambarkan secara sistematik dan akurat fakta dan karakteristik mengenai populasi. Pada penelitian ini peneliti hanya akan sampai pada taraf Eksposisi yaitu menganalisis dan menyajikan fakta secara sistematik sehingga dapat lebih mudah untuk dipahami dan disimpulkan.

Subjek penelitian mencakup semua pihak yamg dapat memberikan informasi yang diperlukan dalam penelitian ini. Subjek dalam penelitian ini adalah kata penghubung. Sedangkan objeknya adalah analisis kata penghubung pada cerpen karangan Mahasiswa Teknik Informatika Kelas I.F Universitas Cokroaminoto Palopo. Sumber Data Dalam penelitian ini ada 2 sumber data yang disajikan.

1. Sumber Data Primer

Sumber data primer adalah sumber utama penelitian yang diproses langsung dari sumbernya tanpa lewat perantara (Mahasiswantoro, 2005: 54). Sumber data primer dalam penelitian ini adalah karangan eksposisi Mahasiswa Teknik Informatika Kelas I.F Universitas Cokroaminoto Palopo.

2. Sumber Data Sekunder

Sumber data sekunder adalah sumber data yang diperoleh secara tidak langsung atau lewat perantara tetapi masih berdasarkan pada kategori konsep (Mahasiswantoro, 2005: 54). Sumber data sekunder dalam penelitian ini adalah buku pustaka, karangan Mahasiswa. 


\section{Desain Penelitian}

Desain pada penelitian ini adalah desain one group pretest-postest. Penggunaan desain ini dapat dilakukan dengan membandingkan tingkat hasil belajar sebelum penerapan pembelajaran dengan penggunaan pendekatan kontekstual dalam kemampuan menulis karangan eksposisi dengan tingkat hasil belajar dalam kemampuan menulis karangan eksposisi. Untuk lebih jelasnya desain, penelitian ini dapat digambarkan sebagai berikut:

\section{Lokasi dan Waktu Penelitian}

1. Lokasi Penelitian

Lokasi penelitian ini adalah Universitas Cokroaminoto Palopo.

2. Waktu penelitian

Penelitian ini dilaksanakan pada semester Ganjil tahun pelajaran 2018/2019.

\section{Teknik Pengumpulan Data}

Teknik pengumpulan data adalah cara-cara yang dipakai untuk mengumpulkan data yang diperlukan. Tujuan utama dari penelitian adalah mendapatkan data, tanpa mengetahui teknik pengumpulan data, maka peneliti tidak akan mendapatkan data yang memenuhi standar data yang ditetapkan (Sugiyono, 2011:224).

Teknik pengumpulan data yang dipakai sebagai berikut :

1. Teknik observasi adalah teknik pengumpulan data dengan cara melakukan pengamatan langsung terhadap objek yang diteliti.

2. Dokumen merupakan catatan peristiwa yang sudah berlaku. Dokumen biasannya berbentuk tulisan, gambar, atau karya-karya monumental dari seseorang, dokumen yang berbentuk gambar misalnnya foto, gambar hidup, sketsa, dan lain-lain (Sugiyono, 2011:240) Teknik dokumentasi adalah teknik pengumpulan data dengan cara mencari data mengenai catatan, transkip, surat kabar, majalah, dan lain-lain.

3. Metode simak merupakan metode penyediaan data yang dilakukan dengan cara menyimak penggunaan bahasa yang menggunakan teknik dasar yang berwujud teknik sadap. Penyadapan penggunaan bahasa tertulis, karena peneliti berhadapan dengan penggunaan bahasa yang berupa bahasa tulis (Mahsun, 2005: 90).

4. Teknik catat adalah mencatat beberapa bentuk yang relevan bagi penelitanya dari penggunaan bahasa secara tertulis. Apabila peneliti berhadapan dengan penggunaan bahasa secara tertulis dalam penyadapan itu peneliti hanya menggunakan teknik catat sebagai gandengan teknik simak (Mahsun, 2005: 92). 


\section{Definisi Operasional Penelitian}

Definisi operasional variabel yaitu merumuskan, mengenal, dan memahami suatu objek yang dirumuskan lebih rinci dari suatu definisi sebagai berikut.

1. Menulis adalah kemampuan seseorang dalam melukiskan lambang grafis yang dimengerti oleh penulis bahasa itu sendiri maupun orang lain yang memiliki kesamaan pengertian terhadap simbol bahasa tersebut.

2. Karangan eksposisi merupakan jenis karangan yang menyajikan penjelasan atau memaparkan beberapa pengetahuan maupun informasi secara lebih jelas dan lebih rinci. Pada karangan eksposisi terdapat fakta data yang mendukung, menjadikan semakin jelas informasi yang diperoleh tersebut.

\section{Populasi dan Sampel}

Populasi

Populasi adalah wilayah generalisasi yang terdiri atas objek/subjek yang mempunyai kualitas dan karakteristik tertentu yang diterapkan oleh peneliti untuk dipelajar dan kemudian ditarik kesimpulannya. Jadi, populasi bukan hanya orang, tetapi juga objek dan benda-benda alam yang lain.

Populasi dalam penelitian ini adalah Mahasiswa Teknik Informatika Kelas I.F Universitas Cokroaminoto Palopo yang berjumlah 40 orang. Untuk lebih jelasnya, penyebaran Mahasiswa Teknik Informatika Kelas I.A Universitas Cokroaminoto Palopo berdasarkan kelas ditunjukkan pada tabel dibawah ini.

Tabel 2 Tabel keadaan mahasiswa

\begin{tabular}{ccccc}
\hline No & Kelas & Laki-laki & Perempuan & Jumlah \\
\hline 1 & I.A & 17 & 23 & 38 \\
\hline
\end{tabular}

(Sumber: tata usaha Universitas Cokroaminooto Palopo, tahun ajaran 2018/2019)

\section{Teknik Analisis Data}

Analisis deskriptif digunakan untuk menganalisis data hasil belajar mahasiswa. Analisis deskriptif bertujuan untuk melihat gambaran suatu data secara umum.

Statistik deskriptif adalah statistik yang digunakan untuk menganalisa data dengan cara mendeskripsikan atau menggambarkan data yang terkumpul sebagaimana adanya tanpa bermaksud membuat kesimpulan yang berlaku untuk umum atau generalisasi. Data yang telah dikumpulkan dengan menggunakan instrumen-instrumen dianalisis secara kuantitatif, deskriptif (berupa hasil belajar).

Hasil belajar merupakan bagian terpenting dalam pembelajaran.Hasil belajar adalah kemampuan yang dimiliki mahasiswa setelah menerima pembelajaran. Hasil belajar dapat dilihat melalui kegiatan evaluasi yang bertujuan untuk mendapatkan data pembuktian yang akan menunjukkan tingkat kemampuan mahasiswa mencapai tujuan pembelajaran. 
Jurnal Onoma: Pendidikan, Bahasa dan Sastra PBSI FKIP Universitas Cokroaminoto Palopo Volume 6 Nomor 2
ISSN 2443-3667 (print)

ISSN 2715-4564 (online)

\section{Hasil dan Pembahasan}

Pada bagian pembahasan ini akan diuraikan hasil analisis data yang telah diteliti. Pemecahan masalah tersebut, dapat dilihat dari hasil analisis data. Hasil penelitian disajikan dalam bentuk kualitatif yaitu gambaran tentang analisis penggunaan kata penghubung dalam karangan Eksposisi Mahasiswa Teknik Informatika Kelas I.F Universitas Cokroaminoto Palopo yang dinyatakan dengan hasil analisis kata penghubung pada karangan Mahasiswa. Data yang diperoleh dalam penelitian ini akan diolah dan dianalisis secara deskriptif dengan teknik analisis data. Penelitian ini dilakukan di Teknik Informatika Kelas I.F Universitas Cokroaminoto Palopo. Penelitian ini mengangkat judul "Analisis Kata Penghubung pada Karangan Eksposisi Mahasiswa".

1. Penggunaan kata penghubung "dan, serta, lagi", digunakan untuk menyatakan gabungan pada suatu kata atau kalimat.

Contoh:

Dia adalah anak yang baik dan suka menolong. Dia mempunyai kakak bernama saiful dana diknya bernama atlas. Kata penghubung "dan" berperan sebagai penggabungan antara dua kalimat, antara baik dan suka menolong, atau saiful dan adiknya bernama atlas. Peran kata penghubung "dan" pada kalimat ini dimaksudkan agar pembaca mengerti maksud kalimat dari penulis, sehingga penulis menggunakan kata penghubung dan.

2. Penggunaan Kata Penghubung Serta

Penggunaan kata penghubung serta disini juga bertujuan untuk menyatakan penggabungan suatu kata maupun kalimat, agar lebih jelas dipahami maknannya, Setelah puas bermain, ani serta keluargannya pun mencari tempat untuk makan.

3. Penggunaan kata penghubung "Sehingga, ketika, setelah, sebelum, sesudah, maka, sering digunakan untuk menyatakan waktu. Berikut beberapa contoh mengenai kata penghubung yang menyatakan waktu.

Contoh :

Karena hari itu masih pagi maka udara masih dingin dan sejuk, sehingga banyak burung yang bernyanyian. Kata penghubung sehingga disini menunjukan waktu, penulis memilih kata penghubung sehingga karena dia ingin menunjukan bahwa hari masih pagi sehingga banyak burung yang bernyayian.

Kami sangat khidmat dalam mengikuti upacara, sehingga tidak ada Mahasiswa yang berbicara ketika upacara berlangsung. Dari kalimat diatas peneliti dapat menyimpulkan bahwa penulis sedang menggambarkan suasana waktu yang tenang dengan ditandai kata penghubung sehingga.

4. Penggunaan Kata Penghubung Ketika

Pada suatu hari ketika hujan deras mengguyur desaku. Ketika hujan sudah berhenti, para warga pun mulai membersihkan rumah mereka. Penulis menggunakan kata penghubung ketika pada kalimat diatas karena dia ingin menunjukan waktu dimana kejadian itu dimulai. 
Jurnal Onoma: Pendidikan, Bahasa dan Sastra PBSI FKIP Universitas Cokroaminoto Palopo Volume 6 Nomor 2
ISSN 2443-3667 (print)

ISSN 2715-4564 (online)

\section{Simpulan}

Berdasarkan hasil penelitian diatas, maka dapat disimpulkan bahwa penggunaan kata penghubung pada karangan mahasiswa dalam membuat kalimat maupun karangan Eksposisi dapat dikatakan sudah cukup baik, hal ini terbukti dari penggunaan kata penghubung yang digunakan oleh Mahasiswa dalam membuat karangan Eksposisi. Akan tetapi masih ada sedikit Mahasiswa yang dalam membuat kalimat maupun karangan Eksposisi hanya berfokus pada kata-kata yang sering dipergunakan. Bentuk kata pengubung yang sering digunakan Mahasiswa pada karangan Eksposisi ini antara lain kata penghubung "dan, sehingga, tetapi, dengan, meskipun, walaupun, setelah, sesudah, maka, serta, kemudian, ketika, sebelum, agar". Dari hasil data diatas dapat dilihat bahwa penggunaan kata penghubung yang paling sering digunakan adalah kata penghubung"dan".Hal ini terlihat dari setiap karangan Mahasiswa selalu menggunakan kata penghubung "dan" yang berfungsi sebagai penggabungan kalimat. 
Jurnal Onoma: Pendidikan, Bahasa dan Sastra

ISSN 2443-3667 (print)

PBSI FKIP Universitas Cokroaminoto Palopo

ISSN 2715-4564 (online)

Volume 6 Nomor 2

\section{Daftar Pustaka}

Ambari, Abdullah. 1983. Intisari Tata Bahasa Indonesia. Bandung: Djatnika.

Chaer, Abdul.2007. Linguistik Umum, Jakarta: PT.RinekaCipta

Kridalaksana, Harimurti. 1986. Kelas Kata dalamBahasa Indonesia. Jakarta: Gramedia

Mahsun. 2005. Metode Penelitian Bahasa. Jakarta: PT Raja GrafindoPersada

Mahasiswantoro.2000. Apresiasi Puisi-puisi Sastra Inggris. Surakarta: Muhammadiyah University Press.

Subroto, Edy. 1992. Pengantar Metode Penelitian Linguistik Stuktural. Surakarta: Sebelas Maret Press. 